\title{
Role of Potassium and Nitrogen on Growth, Yield and Quality of Turmeric (Curcuma longa L.) cv. "Suranjana" under Alluvial Plains of West Bengal
}

\author{
C. Tania $^{1^{*}}$, R. Chatterjee ${ }^{2}$, P. K. Chattopadhyay ${ }^{2}$, A. Phonglosa ${ }^{3}$, \\ T. Basanta ${ }^{1}$ and J. W. Haobijam ${ }^{4}$ \\ ${ }^{1}$ ICAR RC NEHR Manipur Centre, Lamphelpat, India \\ ${ }^{2}$ Department of Spices and Plantation Crops, Faculty of Horticulture, Bidhan Chandra Krishi \\ Viswavidyalaya, Mohanpur, Nadia, West Bengal, India \\ ${ }^{3}$ Directorate of Extension Education, Odisha University of Agriculture and Technology, \\ Bhubaneshwar, India \\ ${ }^{4}$ Department of Agricultural Extension Education, P.S.B, Visva-Bharati, India \\ *Corresponding author
}

\section{A B S T R A C T}

\begin{tabular}{|l|}
\hline K e y w o r d s \\
Turmeric \\
$\begin{array}{l}\text { Curcuma longa } \\
\text { Potassium and } \\
\text { Nitrogen }\end{array}$ \\
\hline Article Info \\
\hline $\begin{array}{l}\text { Accepted: } \\
\text { 04 December } 2020 \\
\text { Available Online: } \\
\text { 10 January 2021 }\end{array}$ \\
\hline
\end{tabular}

The field experiment on turmeric was carried out at Horticultural Research Station, Mondouri, West Bengal of the Faculty of Horticulture, Bidhan Chandra Krishi Viswavidyalaya during 2012-13 and 2013-14 to evaluate the effect of potassium and nitrogen on turmeric cv. "Suranjana" for growth and yield. The design of the experiment was two factorial R.B.D with 8 treatments and three replications. The treatments consisted of four levels of potassium $\left(\mathrm{K}_{2} \mathrm{O} @\right.$ $80,120,160$ and $200 \mathrm{~kg} / \mathrm{ha}$ ) and two spray schedule of N @ 2\% as foliar spray of urea. Results obtained in the present investigation reveal that the maximum vegetative growth parameters like plant height $(149.72 \mathrm{~cm})$, number of tillers per plant (3.23) and number of leaves per plant (18.40) were recorded with the application of potassium and nitrogen i.e, $\mathrm{K}_{2} \mathrm{O} @ 200 \mathrm{~kg} / \mathrm{ha}+\mathrm{N}$ @ 2\% double spray as compared with sole effect of both the nutrients. Yield and yield attributing characters were also found to be influenced much with the application of potassium and nitrogen. Application of $\mathrm{K}_{2} \mathrm{O} @ 200 \mathrm{~kg} / \mathrm{ha}+\mathrm{N} @ 2 \%$ double spray also proved beneficial and showed significant variation in mother rhizome production, primary rhizome and secondary rhizome per clump. The sole application of $\mathrm{K}_{2} \mathrm{O} @ 200 \mathrm{~kg} / \mathrm{ha}$ also proved effective towards the number of primary rhizomes. The combined application of $\mathrm{K}_{2} \mathrm{O} @ 200 \mathrm{~kg} / \mathrm{ha}+\mathrm{N} @ 2 \%$ double spray indicated better rhizome production through improvement of length and weight as also secondary rhizome production per clump. The application of $\mathrm{K}_{2} \mathrm{O} @ 200 \mathrm{~kg} / \mathrm{ha}+\mathrm{N} @ 2 \%$ double spray recorded significant influence on the yield per hectare $(36.82 \mathrm{t} / \mathrm{ha})$. The sole application of potassium and nitrogen also showed significant variation with respect to yield per hectare. A progressive increase with the oleoresin content of turmeric was recorded with the increasing doses of potassium and the number of sprays of nitrogen. However, the highest oleoresin content was recorded from the treatment $\mathrm{NS}_{2} \mathrm{~K}_{4}(10.50 \%)$. The curcumin content also influence significantly with sole application of potassium and nitrogen. The application of $\mathrm{K}_{2} \mathrm{O} @ 160 \mathrm{~kg} / \mathrm{ha}+\mathrm{N} @ 2 \%$ single spray recorded higher curcumin content $(6.19 \%)$ of turmeric as compared to double spray of $\mathrm{N}$. 


\section{Introduction}

Turmeric is known as the 'Golden Spice' as well as the 'Spice of life' is one of the most important ancient medicinal spice, traditionally ubiquitous and held sacred. Turmeric (Curcuma longa L.; syn. Curcuma domestica Value, Amomum curcuma Jacq.) belongs to the family - Zingiberaceae. Nearly 40 species of the genus - 'Curcuma' exist in India while Curcuma longa L. alone contribute commercial production to an extent of $96 \%$. The history of turmeric is entwined with the history of Indian culture and also with the socio-religious practices of the country. It was popular even in Vedic times because of its unique properties of colour, flavour and also its importance as medicine in Ayurveda, besides its use as a cosmetic and significance in religious ceremonies and auspicious occasions (Jacob, 1995). The demand of turmeric increased all over the world as new ingredients of therapeutic and life saving properties were discovered. Turmeric is the major spice in which maximum number of products has been patented.

Turmeric is a heavy feeder of $\mathrm{N}$ and $\mathrm{K}$ nutrients and $\mathrm{K}$ uptake is comparatively higher than N. According to Saifudeen (1981), the uptake of nutrients increased with the increase in dry matter production and generally the phase of active vegetative growth is the period during which there is maximum uptake of nutrients. Further, it was evident from studies conducted by Rao and Rao (1988) that the uptake of nutrients was higher up to third month for potassium, up to fourth month for nitrogen and up to fifth month for phosphorous indicating the need for earlier application of N, P and K fertilizers for improving the plant growth. Specially $\mathrm{N}$ and $\mathrm{K}$ are two important fertilizers for boosting growth and yield of turmeric. Banafer et al., (1995) and Sugtto et al., (1995) reported that with the increase in $\mathrm{K}$ levels growth, leaves number, tillers number and rhizome yield increased. Similarly, Pawer et al., (1992) and Pandey (1992) stated that increasing rates of $\mathrm{N}$ significantly progressed the yield and other yield contributing characters of turmeric. The informations on the nutritional requirements is meagre particularly $\mathrm{K}$ and $\mathrm{N}$ of this crop especially in the plains of West Bengal.

\section{Materials and Methods}

The field trial on turmeric was carried out at Horticultural Research Station, Mondouri, Nadia West Bengal of the Faculty of Horticulture, Bidhan Chandra Krishi Viswavidyalaya during 2012-13 and 2013-14 for two consecutive years. The research station is situated at $23.5^{\circ} \mathrm{N}$ latitude and $89^{\circ} \mathrm{E}$ longitude with an average altitude of $9.75 \mathrm{~m}$ above mean sea level. The soil of the experimental site is typical Gangetic Alluvial soil (Inceptisols) having sandy loam texture, well drained with medium fertility status. The climatic condition of the experimental site is sub-humid. The design of the experiment was two factors factorial RBD with 8 treatments. There were 4 levels of K $(80,120,160$ and 180 $\mathrm{kg} / \mathrm{ha})$ and two spray schedule of nitrogen $\left(1^{\text {st }}\right.$ spray@90 days and $2^{\text {nd }}$ spray @ 90 and 120 days after planting) replicated thrice. A plot size of $1.5 \times 1.5 \mathrm{~m}$ was used with spacing of $25 \times 30 \mathrm{~cm}$. FYM @ $20 \mathrm{t} / \mathrm{ha}$ was applied at the time of land preparation and $\mathrm{N}$ and $\mathrm{P} @$ 60:50 and four levels of $\mathrm{K}_{2} \mathrm{O}$ i.e. 80. 120, 160 and $200 \mathrm{~kg} / \mathrm{ha}$ were also applied. Full dose of $\mathrm{P}_{2} \mathrm{O}_{5}$ and half dose of $\mathrm{K}_{2} \mathrm{O}$ were applied as basal at time of planting. Half recommended dose of $\mathrm{N}$ was applied 45 days after planting (DAP). The remaining doses of $\mathrm{N}$ and $\mathrm{K}_{2} \mathrm{O}$ were applied 90 DAP and earthing up was done after top dressing. All necessary intercultural operations were done as needed by the experiment. The data collected from the field were subjected to statistical analysis 
to the Two factors factorial R.B.D. by following procedure laid out by Gomez and Gomez, (1984). For determination of standard error of mean (S. Em. \pm ) and the value of critical difference (C. D) between the treatment means as 5\% level of significance.

\section{Results and Discussion}

\section{Effect of nitrogen}

The effect of $\mathrm{N}$ on growth, yield and yield attributes of turmeric are presented in table 1 . It is revealed that plant height, number of tillers per plant, number of leaves per plant, leaf length and leaf width, number of mother rhizome, number of primary finger, number of secondary finger and projected yield per hectare were influenced by $\mathrm{N}$ application (as foliar spray). It was evident that $\mathrm{N} @ 2 \%$ double spray recorded maximum plant $(146.36 \mathrm{~cm})$, number of tillers per plant (2.81), number of leaves per plant (14.88), leaf length $(71.95 \mathrm{~cm})$, leaf width $(16.21 \mathrm{~cm})$, number of mother rhizome per clump (2.09), number of primary finger (7.87), number of secondary finger (19.65) and projected yield (32.84 t/ha), oleoresin content (9.18\%). However highest curcumin content of $(5.79 \%)$ was recorded when $\mathrm{N} @ 2 \%$ single spray was applied. The sole effect of potassium and nitrogen as foliar spray $2 \% \mathrm{~N}$ as urea and their interactions had a positive influence on plant height of turmeric plant. The increased in growth attributes of turmeric with increase in $\mathrm{N}$ application may be explained in the fact that nitrogen being active constituent of protoplasm enzyme and chlorophyll, plays a role of catalytic agent in physiological processes, accelerate cell division and speed up the photo assimilation which in turn boost the plant growth and improve the plant structures (Pandey, 1992). The present finging reported in this dissertation agrees with other investigators working on turmeric (Shah and Muthuswami,
1981; Balashanmugam and Chezhiyan, 1986: Singh and Singh, 1988). Curcumin content was influenced much due to single spray $(5.79 \%)$ of nitrogen while double spray showed a reduction $(5.23 \%)$ in this respect. The interaction effect did not showed any consistent variation with regard to curcumin content of turmeric.

\section{Effect of potassium}

It is observed that $\mathrm{K}$ had significant effect on the growth, yield character, yield and quality of turmeric. It is evident that with the increase of $\mathrm{K}_{2} \mathrm{O}$ levels, growth parameter like plant height, number of tillers per plant, number of leaves per plant and leaf length of turmeric, projected yield per hectare and oleoresin content increased progressively. All the yield parameters increased simultaneously with the increase of $\mathrm{K}$ upto $200 \mathrm{~kg} \mathrm{~K}_{2} \mathrm{O} / \mathrm{ha}$ Among the four levels of potassium $(80,120,160$ and $200 \mathrm{~kg} / \mathrm{ha}$ ), the highest plant height (147.53 $\mathrm{cm}$ ), number of tillers per plant (3.19), number of leaves per plant (16.50), leaf length $(75.32 \mathrm{~cm})$, number of mother rhizome (2.66), number of primary finger (8.50), number of secondary finger (20.48), projected yield per hectare (35.99 t/ha) and oleoresin content (9.94\%) was recorded with $\mathrm{K}_{2} \mathrm{O} @ 200 \mathrm{~kg} / \mathrm{ha}$. However the maximum curcumin content was recorded with the treatment $\mathrm{K}_{2} \mathrm{O} @ 160 \mathrm{~kg} / \mathrm{ha}$ (6.38\%). Banafer et al., (1995) and Sugtto et al., (1995) reported that with the increase in $\mathrm{K}$ levels growth, number of leaves, tiller numbers and rhizome yield increased which corroborates the findings of the present investigation that high potassium nutrition influenced number of leaf and tiller production which an agreement with the present study. Singh et al., (1998) showed that increasing rates of potassium application had a positive and significant effect on fresh rhizome yield. They noted that with the increase of $\mathrm{K}$ levels, yield contributing characters of turmeric increased 
progressively. They further observed that the effect of $\mathrm{K}$ on turmeric was found more distinct than nitrogen. All the yield parameters increased simultaneously with the increase of $\mathrm{K}$ upto $200 \mathrm{~kg} \mathrm{~K} 2 \mathrm{O} / \mathrm{ha}$. Among four $\mathrm{K}$ levels $(80,120,160$ and $200 \mathrm{~kg}$ $\mathrm{K}_{2} \mathrm{O} / \mathrm{ha}$ ), $200 \mathrm{~kg} \mathrm{~K}_{2} \mathrm{O} / \mathrm{ha}$ was found to be best with respect to the highest number of mother rhizome, number of primary finger, number of secondary finger and highest turmeric yield
(35.99 t/ha) was recorded with $\mathrm{K}$ level (200 $\mathrm{kg} \mathrm{K}_{2} \mathrm{O} / \mathrm{ha}$ ). Sugtto et al., (1995) supported reported that $\mathrm{K}$ increased the plant growth and rhizome yield with increase of $\mathrm{K}$ levels. The present study also revealed that turmeric responds positively to higher level of potassium in terms of oleoresin content. The highest oleoresin content of $9.94 \%$ was obtained with $\mathrm{K}_{2} \mathrm{O} @ 200 \mathrm{~kg} / \mathrm{ha}$.

Table.1 Effect of potassium, nitrogen and their interaction on plant height, no. of tillers per plant, leaf length, leaf width, no. of mother rhizome, no. of primary fingers, no. of secondary fingers, projected yield/ha, oleoresin and curcumin

\begin{tabular}{|c|c|c|c|c|c|c|c|c|c|c|c|}
\hline Treatme & $\begin{array}{l}\text { Plant } \\
\text { height } \\
\text { (cm) }\end{array}$ & $\begin{array}{l}\text { No. of } \\
\text { tillers } \\
\text { /plant }\end{array}$ & $\begin{array}{l}\text {. of lea } \\
\text { /plant }\end{array}$ & $\begin{array}{c}\text { eaf leng } \\
\text { (cm) }\end{array}$ & $\begin{array}{l}\text { eaf widt } \\
\text { (cm) }\end{array}$ & $\begin{array}{l}\text { No. of } \\
\text { mother } \\
\text { rhizome }\end{array}$ & $\begin{array}{l}\text { No. of } \\
\text { Primary } \\
\text { finger }\end{array}$ & $\begin{array}{l}\text { No. of } \\
\text { econdar } \\
\text { finger }\end{array}$ & i & $\begin{array}{l}\text { leoresi } \\
(\%)\end{array}$ & $\begin{array}{c}\text { Curcumin } \\
(\%)\end{array}$ \\
\hline $\mathbf{N S}_{1}$ & 139.48 & 2.56 & 13.03 & 70.57 & 15.61 & 2.04 & 7.57 & 18.70 & 31.37 & 8.32 & 5.79 \\
\hline $\mathbf{N S}_{2}$ & 146.36 & 2.81 & 14.88 & 71.95 & 16.21 & 2.09 & 7.87 & 19.65 & 32.84 & 9.18 & 5.23 \\
\hline $\operatorname{S.Em}( \pm)$ & 0.728 & 0.016 & 0.167 & 0.358 & 0.047 & 0.007 & 0.050 & 0.368 & 0.061 & 0.072 & 0.111 \\
\hline$D .(P=0.0$ : & 2.124 & 0.046 & 0.487 & NS & 0.137 & 0.022 & 0.147 & NS & 0.177 & 0.210 & 0.323 \\
\hline$K_{1}$ & 136.39 & 2.42 & 11.62 & 66.11 & 14.93 & 1.68 & 7.32 & 18.68 & 29.57 & 7.83 & 4.65 \\
\hline $\mathbf{K}_{2}$ & 142.63 & 2.50 & 13.05 & 70.05 & 15.88 & 1.82 & 7.34 & 19.26 & 30.67 & 39 & 5.18 \\
\hline $\mathbf{K}_{\mathbf{3}}$ & 145.13 & 2.62 & 14.66 & 73.56 & 16.71 & 2.09 & 7.72 & 18.28 & 32.19 & 8.85 & 6.38 \\
\hline $\mathbf{K}_{4}$ & 147.53 & 3.19 & 16.50 & 75.32 & 16.14 & 2.66 & 8.50 & 20.48 & 35.99 & 9.94 & 5.82 \\
\hline S.Em( \pm$)$ & 0.840 & 0.018 & 0.193 & 0.413 & 0.054 & 0.009 & 0.058 & 0.425 & 0.070 & 0.083 & 0.128 \\
\hline D. $(P=0.0$ & 2.434 & 0.053 & 0.559 & 1.198 & 0.157 & 0.025 & 0.168 & 1.230 & 0.203 & 0.241 & 0.370 \\
\hline $\mathbf{N S}_{1} \mathbf{K}_{1}$ & 128.53 & 2.26 & 11.30 & 65.28 & 14.57 & 1.65 & 7.33 & 18.20 & 28.87 & 7.68 & 4.74 \\
\hline $\mathbf{N S}_{1} \mathbf{K}_{2}$ & 139.97 & 2.36 & 12.21 & 66.64 & 15.40 & 1.90 & 7.11 & 19.33 & 30.13 & 7.86 & 5.42 \\
\hline $\mathbf{N S}_{1} \mathbf{K}_{3}$ & 144.08 & 2.47 & 14.02 & 74.96 & 16.46 & 2.17 & 7.44 & 17.38 & 31.32 & 8.38 & 6.79 \\
\hline $\mathrm{NS}_{1} \mathrm{~K}_{4}$ & 145.33 & 3.14 & 14.59 & 75.39 & 16.01 & 2.44 & 8.39 & 19.91 & 35.17 & 9.38 & 6.19 \\
\hline $\mathbf{N S}_{2} \mathbf{K}_{1}$ & 144.25 & 2.58 & 11.93 & 66.94 & 15.29 & 1.72 & 7.31 & 19.17 & 30.27 & 7.98 & 4.56 \\
\hline $\mathbf{N S}_{2} \mathbf{K}_{2}$ & 145.30 & 2.65 & 13.90 & 73.46 & 16.35 & 1.74 & 7.57 & 19.20 & 31.20 & 8.93 & 4.94 \\
\hline $\mathbf{N S}_{2} \mathbf{K}_{3}$ & 146.18 & 2.77 & 15.30 & 72.16 & 16.95 & 2.00 & 7.99 & 19.19 & 33.07 & 9.31 & 5.98 \\
\hline $\mathbf{N S}_{2} \mathrm{~K}_{4}$ & 149.72 & 3.23 & 18.40 & 75.25 & 16.27 & 2.89 & 8.60 & 21.04 & 36.82 & 10.50 & 5.45 \\
\hline S.Em $( \pm)$ & 1.455 & 0.032 & 0.334 & 0.716 & 0.094 & 0.015 & 0.101 & 0.735 & 0.121 & 0.144 & 0.221 \\
\hline D. $(P=0.0$ & 4.215 & 0.092 & 0.968 & 2.075 & 0.272 & 0.043 & 0.292 & NS & 0.351 & 0.418 & NS \\
\hline
\end{tabular}

$\mathrm{NS}_{1}=$ Single foliar spray N (2\%); $\mathrm{NS}_{2}=$ Double foliar spray N (2\%); $\mathrm{K}_{1}=\mathrm{K}_{2} \mathrm{O} @ 80 \mathrm{~kg} / \mathrm{ha} ; \mathrm{K}_{2}=\mathrm{K}_{2} \mathrm{O} @ 120 \mathrm{~kg} / \mathrm{ha} ; \mathrm{K}_{3}=$ $\mathrm{K}_{2} \mathrm{O} @ 160 \mathrm{~kg} / \mathrm{ha} ; \mathrm{K}_{4}=\mathrm{K}_{2} \mathrm{O} @ 200 \mathrm{~kg} / \mathrm{ha}$

\section{Potassium and nitrogen interaction}

It is also evident from the table 1 that both $\mathrm{N}$ and $\mathrm{K}$ had positive impact on turmeric production. All the growth character and yield influenced significantly with the increase in the level of Potassium and nitrogen. The plant height was found increase significantly with 
the increase in the level of potassium and foliar spray nitrogen twice, the tallest plant $(149.72 \mathrm{~cm})$ was obtained from the treatment $\mathrm{NS}_{2} \mathrm{~K}_{4}\left(\mathrm{~K}_{2} \mathrm{O} @ 200 \mathrm{~kg} / \mathrm{ha}+\mathrm{N} @ 2 \%\right.$ double spray). The number of tillers, leaves and girth of plant also varied significantly among different levels of potassium. Plants received with $\mathrm{K}_{2} \mathrm{O} @ 200 \mathrm{~kg} / \mathrm{ha}+\mathrm{N} @ 2 \%$ double spray recorded the maximum number of mother rhizomes (2.89), number of primary fingers (8.60), number of secondary fingers (21.04). The highest yield of $36.82 \mathrm{t} / \mathrm{ha}$ and the highest oleoresin content $(10.50 \%)$ was also recorded with $\mathrm{K}_{2} \mathrm{O} @ 200 \mathrm{~kg} / \mathrm{ha}+\mathrm{N} @$ $2 \%$ double spray however the highest curcumin content $(5.98 \%)$ was recorded with $\mathrm{K}_{2} \mathrm{O} @ 160 \mathrm{~kg} / \mathrm{ha}+\mathrm{N} @ 2 \%$ double spray. Potassium along with nitrogen and phosphorous plays a major role in growth and yield as it is involved in assimilation, transport and storage tissue development (Tisdale et al., 1985).

The interaction effect did not showed any consistent variation with regard to curcumin content of turmeric. The curcumin accumulation increased with the increased in nutrients (potassium and nitrogen) upto a certain level but more increased with the level of nutrients could not increased further in the content of curcumin. Higher levels of $\mathrm{N}, \mathrm{P}$ and $\mathrm{K}$ fertilization have also been reported to decrease the curcumin content of rhizomes (Rao et al., 1975), which supports the present findings where the curcumin content was found to decrease at the highest dose of potassium and spraying of nitrogen as urea twice. Reports by various workers also suggested that at higher fertility status of soil, there might be some depression in the curcumin content of rhizome (Rao and Reddy, 1978 and Swamy, 1984). The highest curcumin content of $6.79 \%$ was obtained with the treatment $\mathrm{NS}_{1} \mathrm{~K}_{3}\left(\mathrm{~K}_{2} \mathrm{O} @ 160 \mathrm{~kg} / \mathrm{ha}\right.$ $+\mathrm{N} @ 2 \%$ single spray) indicating that this combination is the best for promoting curcumin content of turmeric. Curcumin concentration of rhizome is a fair indicator of quality turmeric.

It is concluded from the two years data that application of $\mathrm{K}_{2} \mathrm{O} @ 200 \mathrm{~kg} / \mathrm{ha}+\mathrm{N} @ 2 \%$ double spray proved most effective by influencing different growth parameters, yield and yield component as also quality constituent in turmeric cv. Suranjana under the alluvial soil of West Bengal.

\section{References}

Balashanmugam, P.V. and Chezhiyan, N. (1986). Effect of differential application of nitrogen on growth and yield of turmeric (Curcuma longa L.). Madras Agril. J. 73: 439-442.

Banafar, R. B. S. and Tiwari, R. J. (1995) Response of turmeric (Curcuma longa L.) to potassium application in medium black soils of Madhya Pradesh. Crop Res. Hisar. 10: 93-95.

Gomez, K. A. and Gomez, A. A. (1984). Statistical procedures for Agricultural research ( $2^{\text {nd }}$ edition). A Wiley Int. Sci. Pub. New York. pp: 20-30.

Jacob, B. (1995). Turmeric - quality requirements of importing countries. In Quality improvement of turmeric, Ed. C.R. Sivadasan and N.A. Devananda Shenoy. Spices Board (Govt. of lndia) Kochi. pp. 25-36.

Pandey, A. K. (1992). Response of turmeric to various levels of nitrogen under terrace conditions of mid-altitude Mizoram. Indian Cocoa, Arecanut and Spices J., 16: 14-16.

Pawar, H. K. and Gavande, S. S. (1992). Content and uptake of NPK by ginger rhizomes as influenced by irrigation and nitrogen management. $J$. Maharashtra Agril. Univ. 17: 282-283.

Rama, Rao, M., Reddy, Ramakrishna, V. (1978). Effect of $N, P, K$ fertilization 
on curing percentage and curcumin content of turmeric (Curcuma longa L.). Indian J. Hort. 35: 143-144.

Rao, M. R., Reddy, K. R. C. and Subbarayudu, M. (1975). Promising turmeric types of Andhra Pradesh. Indian spices, 12: 2-13.

Saifudeen, N. (1981). Foliar diagnosis, yield and quality of turmeric (Curcuma longa L.) in relation to nitrogen, phosphorus and potassium. M.Sc. (Ag.) Thesis, submitted to Kerala Agricultural University, Thrissur, Kerala, India.

Shah, H. A. and Muthuswami, S. (1981) Studies on the influence of nitrogen on yield components of turmeric (Curcuma longa L.). Indian Cocoa, Arecanut and Spices J., 5: 9-10
Singh, N. P. and Singh, R. S. (1988). A note on the effect of various levels of nitrogen on growth and yield of turmeric (Curcuma longa L.). Haryana J. Hort. Sci., 17: 125-126.

Sugtto, Y. and Ma Fluchah. (1995). Influence of rates of farmyard manure and $\mathrm{KCl}$ on growth, yield and quality of young ginger rhizome. Agrivita. 18: 67-73.

Swami, G. S. (1984). Studies on the effect of $\mathrm{N}, \mathrm{P}$ and $\mathrm{K}$ on growth, yield and quality of turmeric. South Indian Hort., 32: 288-291.

Tisdale, S. L., Nelson, W. L. and Beaton, T. D. (1985) Soil Fertility and Fertilizer. $4^{\text {th }}$ edition, Macmillan Publ. Co., New York.

\section{How to cite this article:}

Tania, C., R. Chatterjee, P. K. Chattopadhyay, A. Phonglosa, T. Basanta and Haobijam, J. W. 2021. Role of Potassium and Nitrogen on Growth, Yield and Quality of Turmeric (Curcuma longa L.) cv. "Suranjana" under Alluvial Plains of West Bengal. Int.J.Curr.Microbiol.App.Sci. 10(01): 7-12. doi: https://doi.org/10.20546/ijcmas.2021.1001.002 